\title{
ENZYMATIC HYDROLYSIS OF FAST-GROWING POPLAR WOOD AFTER PRETREATMENT BY STEAM EXPLOSION
}

\author{
ANNA GAŁĄZKA* and JAN SZADKOWSKI** \\ *Warsaw University of Life Sciences - SGGW, Faculty of Wood Technology, \\ Nowoursynowska 159 C, 02-787 Warsaw, Poland \\ **Warsaw University of Life Sciences-SGGW, Department of Wood Science and Wood Preservation, \\ Institute of Wood Sciences and Furniture, Nowoursynowska 159 C, 02-787 Warsaw, Poland \\ ๑Corresponding author: A. Gatazka, anna.galazka1995@gmail.com
}

Received January 11, 2021

The aim of the present study was to investigate the effect of steam explosion pretreatment, without maintaining the heating temperature, on the yield of enzymatic hydrolysis of wood biomass. Genetically modified poplar wood was used for the investigation. The pretreatment process was conducted at temperatures of $160{ }^{\circ} \mathrm{C}, 175{ }^{\circ} \mathrm{C}, 190{ }^{\circ} \mathrm{C}$ and 205 ${ }^{\circ} \mathrm{C}$. Then, the system was rapidly decompressed. The heating medium was water. The chemical composition of biomass was determined before and after the steam explosion and then enzymatic hydrolysis was performed. The results of the chemical composition analysis showed a change in the holocellulose content in the analyzed biomass (about $80 \%$ for the native sample and $72 \%$ for the biomass sample treated at $205{ }^{\circ} \mathrm{C}$ ), a decrease in the hemicelluloses content from about $40 \%$ (native sample) to $16 \%$ for the sample treated at $205{ }^{\circ} \mathrm{C}$. The results of enzymatic hydrolysis showed the lowest glucose extraction efficiency for biomass hydrolysis after the treatment at $160{ }^{\circ} \mathrm{C}$, of only about $9 \%$ compared to the theoretical content of glucose from the cellulose contained in hydrolysed wood biomass. The highest results were obtained for the samples treated at $190{ }^{\circ} \mathrm{C}$ and $205^{\circ} \mathrm{C}$. The study also estimated the processing costs, as a function of the heating medium (steam, water) and energy source (atomic energy, hard coal, natural gas, biomass), assuming heating with electric heaters. From the economic point of view, it is advantageous to use steam heating medium, and either natural gas or biomass as an energy source.

Keywords: enzymatic hydrolysis, fast-growing poplar, pretreatment, biofuels, biomass, steam explosion, process cost

\section{INTRODUCTION}

Nowadays, considering the ecological aspects of chemical processes is very important. Scientists are increasingly alarmed about the impact of greenhouse gases caused by the combustion of conventional fuels (i.e. coal, oil, natural gas, etc.) on the Earth's climate. Since the second half of the twentieth century, research has been underway to develop environmentally friendly fuel technologies that do not cause additional emissions of $\mathrm{CO}_{2}$ and other greenhouse gases into the atmosphere. ${ }^{1,2}$

One of the raw materials used to produce environmentally friendly fuels may be biomass. Biomass is defined as a matter of plant or animal origin that decomposes. ${ }^{3}$ Until now, cereal grains, potatoes, sugar cane, sugar beet, maize, rapeseed and wood have been used as biomass. However, the application of raw materials that are used in the food and other non-fuel industries is being abandoned. ${ }^{4,5}$ Another solution lies in exploiting lignocellulosic biomass, which results as waste from different industries, e.g. food and wood processing industries, or is obtained from special plantations dedicated to these purposes, e.g. fastgrowing plants and genetically modified plants to increase the yield of biomass (trees, shrubs, grasses, etc. $\left.{ }^{6-8}\right)$. The main components of lignocellulosic biomass are: cellulose (approx. 3550\%), hemicelluloses (approx. 20-35\%), lignin (approx. 15-20\%) and auxiliary compounds, including extractives (approx. 0.2-14.0\%) and mineral substances (approx. 0.2-1.7\%). ${ }^{9,10}$ These amounts vary for individual components depending on the type of plant or waste. ${ }^{10}$

However, biomass is mainly composed of the lignocellulose complex (LCC), with an anisotropic type of structure, which makes it very difficult to convert to simple substances by carrying out enzymatic hydrolysis, which, on the 
other hand, is an essential stage in the process of obtaining biofuels (bioethanol, biodiesel, etc.) based on green technologies. ${ }^{1,11}$ The development of technologies with the lowest possible energy consumption and environmental impact ${ }^{12,13}$ is an important aspect in biofuel production. Selected pretreatment methods should, therefore, be applied before bioconversion, which will allow more efficient enzymatic hydrolysis and fermentation processes. ${ }^{14,15}$ This is primarily aimed at increasing the proportion of the amorphous cellulose fraction, which is more susceptible to enzymatic hydrolysis, impairing the hemicelluloses structure and removing lignin. ${ }^{9,16}$

The method of pretreatment should be chosen so as to eliminate the loss of sugars (especially glucose) as much as possible, associated with the partial degradation of polysaccharides and limitation of enzyme inhibitors. ${ }^{17-19}$ Physical, physico-chemical, chemical and biological methods are used for the initial preparation of the lignocellulose material. Each of these methods results in a different level of transformation in the LCC zone. ${ }^{9}$ It is assumed that the physicochemical method is the most promising pretreatment, especially steam explosion (SE) ${ }^{20-22}$ This method uses saturated steam or water at elevated temperature $\left(160-290{ }^{\circ} \mathrm{C}\right)$ and pressure (0.69-4.83 MPa). ${ }^{23-25}$ The result of the process and its costs are also influenced by the duration of maintaining the target temperature. ${ }^{26}$ The LCC biomass, sealed in an autoclave tank, is subjected to high temperature and high pressure. The prescribed time is followed by rapid decompression to atmospheric pressure. ${ }^{9,27}$ Hemicelluloses, lignin, cellulose and other organic substances (e.g. tannins) forming the lignocellulose complex are degraded by SE. The formation of glucose, xylose, mannose, galactose, furfural, formic acid and many others is the result of this degradation. These substances degrade as a result of SE, forming substances such as monosaccharides (xylose, galactose, mannose, glucose), formic acid, levulinic acid, vanillin, hydroxymethylfurfural, furfural and others. ${ }^{1,18}$ The material prepared this way is more accessible for hydrolytic enzymes. ${ }^{28}$ It is estimated that the pretreatment with steam explosion saves approx. $70 \%$ of energy consumption, compared to, e.g. physical methods..$^{20,21,29}$ In addition, it allows reducing the amount of waste and costs related to its recycling. ${ }^{30}$

The degradation of hemicelluloses and part of cellulose to monosaccharides consists in the loss of substrates for hydrolysis and subsequent fermentation. Holocellulose has been assumed to be the sum of sugars (cellulose and hemicelluloses) that are part of wood biomass. ${ }^{10}$ In addition, during the pretreatment, the biomass autohydrolysis occurs due to the acidification of the environment in the reactor, causing the decomposition of hemicelluloses and lowpolymerization degree cellulose to simple sugars and derivatives, such as furfural and hydroxymethylfurfural. ${ }^{10,31}$ In addition, the degradation process is largely related to lowpolymerization degree sugars and amorphous structures, ${ }^{1,16}$ which are valuable due to their ease of exposure to hydrolytic enzymes. This reduces the theoretical efficiency of lignocellulosic biomass biofuels. ${ }^{17}$ Additionally, the influence of high temperature and pressure causes the release of metal compounds from biomass and the pretreatment equipment. ${ }^{32,33}$ The released metal compounds permeate the material and may lead to the inhibition of biological processes, such as hydrolysis or fermentation. ${ }^{34,35}$ This makes it necessary to select appropriate process parameters and to select metal alloys used in the manufacture of industrial equipment and its appropriate passivation or coating with chemically inert substances.

Enzymatic hydrolysis consists in breaking down polysaccharides to simple sugars. This process is environmentally friendly, does not require the use of aggressive solvents or chemicals, making it attractive for the production of liquid fuels in green technologies. ${ }^{26,36}$ The removal of enzymes from the resulting mixture (enzyme solution, monosaccharides, biomass residues, etc.) may be carried out by heating the mixture at $90{ }^{\circ} \mathrm{C}$, which results in the denaturation of the protein structures. ${ }^{37}$ The waste from the hydrolysis process can be used in the production of high-protein feed for farm animals. $^{38}$ Hydrolytic enzymes cause the disintegration of $\beta-1,4$ glycosidic bonds in the cellulose polymer structure, leading to the formation of glucose molecules. ${ }^{39,40}$ Enzymatic hydrolysis takes place under mild conditions: $\mathrm{pH}$ 4.8 and temperature of $45-50{ }^{\circ} \mathrm{C}^{41,11}$ The enzymatic hydrolysis process can be carried out parallel to or immediately after the fermentation process. $^{38}$ Although the use of enzymes is environmentally friendly, at present, the high price limits their use on an industrial scale.

This paper attempts to compare the economic aspect of a steam explosion pretreatment process 
with the energy cost of running the process at a higher temperature. Simplifications have been adopted, such as the use of electricity to heat the equipment and the fact that, apart from the pretreatment temperature, all wood biomass undergoes the same preparation cycle for processing. The only variable is the pretreatment temperature, while the other costs remain the same. For the calculations, it was assumed that the process is carried out without energy losses, which could affect the calculation values, but should not significantly affect the difference in the cost-effectiveness of the source of electricity used to heat the medium.

\section{EXPERIMENTAL}

\section{Material}

The wood of five-year old fast-growing poplar (genetically modified MPK-4-11-2) was used for the study. The wood came from the experimental field of the Department of Plant Genetics, Breeding and
Biotechnology, Institute of Biology at the Warsaw University of Life Sciences, located in Wolica $\left(52^{\circ}\right.$ $08^{\prime} 42$ "N 21 $04^{\circ} 07$ "E). The genetic modification consisted in activating the gene responsible for rapid biomass growth. ${ }^{14}$ The material was selected to eliminate defects and then subjected to a process of drying and debarking. The material thus obtained was ground in a laboratory knife mill, then it was divided into fractions using laboratory sieves. For the laboratory determinations and further testing, the chip fraction of 0.43-1.02 mm was used.

For chemical determinations, the following chemicals were used: $65 \%$ nitric acid (V) (analytical grade, Chempur), 96\% ethanol (analytical grade, POCH), Chloroform (analytical grade, Chempur), 99.5\% acetic acid (analytical grade, Chempur), sodium (III) chlorate (analytical grade, Chempur), 95\% sulphuric acid (VI) (analytical grade, $\mathrm{POCH}$ ), and distilled water produced at the Institute of Wood Sciences and Furniture, Department of Wood Science and Wood Preservation (WULS) in Warsaw.

Table 1

Weights of standards for the determination of compounds dissolved in pretreated liquids

\begin{tabular}{lccc}
\hline Standard & Producer & Purity & Weight \\
\hline Glucose & POCH & analytical grade & $1.0119[\mathrm{~g}]$ \\
Xylose & Biochemical & analytical grade & $1.0007[\mathrm{~g}]$ \\
Cellobiose & Sigma-Aldrich & analytical grade & $1.0013[\mathrm{~g}]$ \\
Formic acid $(99 \%)$ & POCH & analytical grade & $0.5[\mathrm{~mL}]$ \\
\hline
\end{tabular}

\section{Methodology}

The experiment comprised two stages. The first one consisted in the preparation of the material, including performing the steam explosion (SE). The second stage included the chemical analyses and enzymatic hydrolysis on native and SE pretreated biomass. The procedure of steam explosion was based on the studies by Marchwicka et al. ${ }^{11}$ and Antczak, ${ }^{42}$ varying the $\mathrm{SE}$ process temperature $\left(160{ }^{\circ} \mathrm{C}, 175^{\circ} \mathrm{C}, 190{ }^{\circ} \mathrm{C}, 205^{\circ} \mathrm{C}\right)$, without maintaining the heating.

Two types of materials were used for enzymatic hydrolysis: the material subjected to the steam explosion pretreatment process and native material from poplar wood. The samples were weighed in sealed screw-capped test tubes with a volume of 10 $\mathrm{cm}^{3}$. The cellulose concentration was $1 \%(\mathrm{w} / \mathrm{w})$. Then, a $5 \mathrm{~cm}^{3}$ of $0.1 \mathrm{M}$ citrate buffer solution (Chempur, Poland), $\mathrm{pH}=4.8$, was added to each sample. The next step consisted in the addition of $0.1 \mathrm{~cm}^{3}$ of a $2 \%$ solution of sodium azide (Chempur, Poland) to each sample in order to prevent the growth of microorganisms during the hydrolysis. ${ }^{37}$ The volume of distilled water was calculated to be $10 \mathrm{~cm}^{3}$. It was added to each sample before the enzyme addition. Finally, $0.332 \mathrm{~cm}^{2}$ of $25 \% \mathrm{v} / \mathrm{v}$ Cellic CTec2 enzyme (mixture of cellulases, $\beta$-glucosidases and hemicellulases) (Novozymes, Bagsvaerd, Denmark) was added to each sample $(0.1 \mathrm{~g}$ of enzyme per $0.1 \mathrm{~g}$ of cellulose). The activity of the enzyme was 129 FPU/MmL, as measured with Wathman No.1 filter paper, according to the NREL method. ${ }^{43}$ The mixture of ingredients for enzymatic hydrolysis prepared and sealed in this way was placed at a temperature of $50{ }^{\circ} \mathrm{C}$ and mixed for $72 \mathrm{~h}$, using a mixer (RM-2M, Elmi, USA), with a rotation speed of $25 \mathrm{rpm}$. After the process, the collected samples were stored in a freezer at $-20{ }^{\circ} \mathrm{C}$ until analysis by HPLC.

The analysis of the obtained hydrolysates was carried out using the method presented in Antczak et $a l .{ }^{42}$ using an HPLC system (LC-20AD, Shimadzu, Japan) that was equipped with a differential refraction detector (RID-10A, Shimadzu, Japan), a pump (LC20AD, Shimadzu, Japan), a DGU-20A deaerator (Shimadzu, Japan), an oven (CTO-20A, Shimadzu, Japan) and a controller (CBM-20A, Shimadzu, Japan). The chromatographic data were processed using LC Solution v. 1.21 SP1 software. For the samples subjected to enzymatic hydrolysis, the conditions for HPLC analysis were as follows: double-distilled water as eluent, column - RHM-Monosaccharide $(300 \mathrm{~mm} \times$ $7.80 \mathrm{~mm}$, Rezex, Torrance, USA) connected to the 
protective column, oven temperature of $80{ }^{\circ} \mathrm{C}$, flow rate of $0.6 \mathrm{~mL} / \mathrm{min}$, injection volume of $20 \mu \mathrm{L}$.

To determine the monosaccharide content, solutions of the standards shown in Table 1 were prepared, from which the calibration curves and their equations were determined. Concentrations of $2: 1,1: 1$, $1: 2$ and 1:8 were used. Before the chromatographic analysis, the samples were brought to room temperature and thawed by heating for $15 \mathrm{~min}$ at $90{ }^{\circ} \mathrm{C}$ in a water bath. Then, the hydrolysate samples were filtered using a nylon syringe filter (pore size of 0.45 $\mu \mathrm{m})$ and the test was carried out on a sample of $10 \mu \mathrm{m}$ per chromatograph vial. The content of sugars (glucose and xylose) in hydrolysates was determined. The developed equations of the calibration curves were as follows:

$\mathrm{y}=3.9 * 10^{-7} \mathrm{x} ; \mathrm{R}^{2}=0.97181526($ glucose $)$

$\mathrm{y}=6.9 * 10^{-7} \mathrm{x} ; \mathrm{R}^{2}=0.99268922$ (xylose)

\section{Chemical analysis of poplar wood samples}

The basic chemical determinations were carried out on the native and SE pretreated materials. The percentage of extractives in the biomass was determined using a 93:7 (w/w) chloroform-ethanol mixture. ${ }^{44}$ Cellulose was determined by the KürschnerHoffer method. ${ }^{45}$ Insoluble lignin was determined by the Klason method according to TAPPI T222 om-02. ${ }^{46}$ Soluble lignin was determined by the Klason method according to TAPPI Class UM 250 (1991). ${ }^{47}$ Holocellulose was determined using sodium (III) chlorate. $^{30,48}$ The hemicelluloses content was calculated as the difference between holocellulose and Kürschner-Hoffer cellulose contents.

\section{Estimation of process costs}

During the steam explosion pretreatment, a proportion of $12.5 \mathrm{~cm}^{3}$ of distilled water per $1 \mathrm{~g}$ of wood biomass was used. The demand for steam as a heating medium was obtained on the basis of saturated steam data in relation to temperature (http://fluid.itcmp.pwr.wroc.pl). It was assumed that, during the experiment, the space occupied by water will be occupied by saturated steam, which made it possible to determine the density of water vapor depending on the assumed process temperature. Electricity prices, depending on the source, were determined on the basis of data published on www.renewable-energysources.com and were as follows: nuclear $-\$ 0.093$, coal with CCS $-\$ 0.12-0.13$, CC natural gas $-\$ 0.043$, biomass $-\$ 0.092$. For the purpose of estimating the costs, no fluctuations in energy prices among countries were taken into account and the 2019 electricity price was adopted. In the calculations, in order to standardize the prices of energy to a global currency, the exchange rate of the US dollar (USD) to the polish zloty (PLN) was adopted, which amounted to: $1 \mathrm{USD}=3.88 \mathrm{PLN}$.
Using the following equation, ${ }^{49}$ the energy requirement $(\mathrm{Q})$ for the steam explosion pretreatment process at the set temperature was estimated:

$\mathrm{Q}=\mathrm{c}^{*} \mathrm{~m} * \Delta \mathrm{T}$

where: Q - energy (heat) supplied [J], c - specific heat $\left[\mathrm{J} / \mathrm{kg}^{*} \mathrm{~K}\right], \mathrm{m}$ - weight $[\mathrm{kg}], \Delta \mathrm{T}-$ temperature gain $[\mathrm{K}]$.

This relationship allows determining the optimal heating medium and a cost-effective electricity source. These may change as a function of the design and technical parameters of commonly used SE installations.

\section{RESULTS AND DISCUSSION Chemical composition of biomass after steam explosion}

The chemical composition of wood biomass obtained from 5-year-old genetically modified poplar before and after steam explosion is presented in Table 2.

Table 2 shows the results of chemical determinations made for the native material and the sample pretreated by the steam explosion method at $160{ }^{\circ} \mathrm{C}, 175{ }^{\circ} \mathrm{C}, 190{ }^{\circ} \mathrm{C}$ and $205{ }^{\circ} \mathrm{C}$, without sustained heating. When determining the extractives using the chloroform-ethanol mixture, a decrease in their content was observed as the temperature of the pretreatment increased. The highest content of extractives was found for the material pretreated at $205{ }^{\circ} \mathrm{C}$ (approx. 2.6\%), while the lowest - for the material pretreated at $190{ }^{\circ} \mathrm{C}$.

The lowest cellulose content was noted for the native material, of about $42 \%$. The values obtained for the pretreated wood biomass showed higher cellulose content by approx. $10 \%$. Meanwhile the highest content of cellulose was found in the material pretreated at $160{ }^{\circ} \mathrm{C}$, amounting to approx. $61 \%$.

The highest content of holocellulose was obtained after the pretreatment at $160{ }^{\circ} \mathrm{C}$ approx. 83\%, while the lowest - after the pretreatment at $205{ }^{\circ} \mathrm{C}-$ of $75 \%$. The remaining native material showed holocellulose content of about $81 \%$.

The highest content of hemicelluloses was noted for the native material, amounting to approx. 39\%, while the lowest - for the material subjected to steam explosion at $205{ }^{\circ} \mathrm{C}$ - of approx. $16 \%$. Such significant differences may be explained by the low resistance of hemicelluloses to the temperature used for the pretreatment. At $190{ }^{\circ} \mathrm{C}$ and $175^{\circ} \mathrm{C}$, the hemicelluloses content is similar, amounting to about 25 and $24 \%$, respectively. Relatively low content of 
hemicelluloses was found at $160{ }^{\circ} \mathrm{C}$ - of about $22 \%$.

The lowest lignin content was observed for the native material - of $17.5 \%$, while the highest - for the material pretreated at $160{ }^{\circ} \mathrm{C}$ and $190{ }^{\circ} \mathrm{C}$, amounting to $22.1 \%$ and $22.4 \%$, respectively. In the case of soluble lignin, it was found that its content was the highest for the pretreated filtrate at $190{ }^{\circ} \mathrm{C}$ and this value was $0.007 \mathrm{mg} / \mathrm{cm}^{3}$. The lowest lignin content in $3 \% \quad \mathrm{H}_{2} \mathrm{SO}_{4}$ acid was obtained after the pretreatment at $160{ }^{\circ} \mathrm{C}$ and 175 ${ }^{\circ} \mathrm{C}$ - about $0.004 \mathrm{mg} / \mathrm{cm}^{3}$ of soluble lignin.
Also, the lignin dissolved in $3 \% \mathrm{H}_{2} \mathrm{SO}_{4}$ was determined for both the native wood biomass and the SE pretreated sample. According to the TAPPI UM $250^{47}$ standard, the aim of this test was to show the percentage of low molecular weight lignin contained in the solid fraction. The results obtained are presented in Table 2. The low molecular weight lignin content in the native material was found to be of $1.0 \%$. As a result of the pretreatment with SE, an increase in the lowmolecular-weight lignin content was observed, most likely due to the decomposition of highmolecular-weight lignin.

Table 2

Chemical composition of 5-year-old genetically modified poplar wood before and after the steam explosion (SE) process

\begin{tabular}{ccccccc}
\hline \multirow{2}{*}{$\begin{array}{c}\text { Temperature } \\
\left({ }^{\circ} \mathrm{C}\right)\end{array}$} & $\begin{array}{c}\text { Extractive } \\
\text { substances }\end{array}$ & $\begin{array}{c}\text { Cellulose } \\
\text { K-H }\end{array}$ & Holocellulose & Hemicelluloses & $\begin{array}{c}\text { Insoluble } \\
\text { lignin }\end{array}$ & $\begin{array}{c}\text { Soluble } \\
\text { lignin }\end{array}$ \\
\hline Native & $2.5 \pm 0.4$ & $41.9 \pm 0.8$ & $81.1 \pm 0.6$ & $39.2 \pm 1.4$ & $17.5 \pm 0.3$ & $1.0 \pm 0.1$ \\
160 & $1.6 \pm 0.1$ & $60.6 \pm 0.7$ & $82.6 \pm 0.5$ & $21.9 \pm 1.2$ & $22.1 \pm 0.3$ & $1.1 \pm 0.1$ \\
175 & $1.5 \pm 0.1$ & $56.4 \pm 0.6$ & $81.1 \pm 0.3$ & $24.7 \pm 0.9$ & $21.2 \pm 0.3$ & $2.9 \pm 0.4$ \\
190 & $1.3 \pm 0.1$ & $56.6 \pm 0.3$ & $80.4 \pm 0.4$ & $23.8 \pm 0.8$ & $22.4 \pm 0.6$ & $3.9 \pm 0.2$ \\
205 & $2.6 \pm 0.2$ & $59.4 \pm 1.4$ & $75.0 \pm 0.6$ & $15.7 \pm 1.9$ & $18.0 \pm 1.3$ & $3.3 \pm 0.3$ \\
\hline
\end{tabular}

Table 3

Monosaccharides content as a function of the temperature of steam explosion pretreatment

\begin{tabular}{ccc}
\hline \multirow{2}{*}{ Temperature } & \multicolumn{2}{c}{ Concentration $(\mathrm{mg} / \mathrm{g})$} \\
\cline { 2 - 3 } & Glucose & Xylose \\
\hline Native & 1.412 & 1.424 \\
$160{ }^{\circ} \mathrm{C}$ & 1.039 & 0.971 \\
$175^{\circ} \mathrm{C}$ & 1.577 & 1.256 \\
$190^{\circ} \mathrm{C}$ & 1.398 & 1.047 \\
$205^{\circ} \mathrm{C}$ & 1.855 & 1.061 \\
\hline
\end{tabular}

Changes in the soluble lignin content were remarked in each stage of the experiment. The lowest content of low-molecular-weight lignin was found for the material pretreated at $160{ }^{\circ} \mathrm{C}-$ of about $1.1 \%$. After the pretreatment at $175^{\circ} \mathrm{C}$, it reached approximately $2.9 \%$. The highest content of low-molecular-weight lignin was noted after the pretreatment at $190{ }^{\circ} \mathrm{C}-$ of $3.9 \%$. For the material pretreated at $205{ }^{\circ} \mathrm{C}$, a decrease to $3.3 \%$ was observed.

Table 3 shows the content of monosaccharides (glucose and xylose) obtained for the analyzed biomass before and after the pretreatment by steam explosion at the selected temperatures. Comparable concentrations of glucose and xylose $(1.41 \mathrm{mg} / \mathrm{g}$ and $1.42 \mathrm{mg} / \mathrm{g}$, respectively) were obtained in the native material. The lowest glucose content was obtained in the material treated at $160{ }^{\circ} \mathrm{C}$ and it was about $1.04 \mathrm{mg} / \mathrm{g}$. This sample also had the lowest xylose content - of $0.97 \mathrm{mg} / \mathrm{g}$. The highest glucose content was obtained after the treatment at $205{ }^{\circ} \mathrm{C}(1.9 \mathrm{mg} / \mathrm{g})$, where the xylose content was approx. $1.06 \mathrm{~mL} / \mathrm{g}$. The highest content of xylose was recorded for the material pretreated at $175{ }^{\circ} \mathrm{C}$, which showed the glucose content of $1.57 \mathrm{mg} / \mathrm{g}$. For the pretreatment at $190{ }^{\circ} \mathrm{C}$, lower concentrations of glucose and xylose than those in the native material were obtained - of $1.4 \mathrm{mg} / \mathrm{g}$ and 1.05 $\mathrm{mg} / \mathrm{g}$, respectively.

Figure 1 shows the yield of glucose in relation to the theoretical content of glucose in cellulose obtained in the analyzed biomass. These results were compared with the content of holocellulose 


\section{ANNA GAŁĄZKA and JAN SZADKOWSKI}

in the analyzed material. The lowest theoretical hydrolysis yield was obtained for the material pretreated at $160{ }^{\circ} \mathrm{C}$. It was about $9 \%$. This material had the highest holocellulose content - of about $83 \%$. According to the data in Table 2, this sample also exhibited the highest cellulose content (over 60\%). This may indicate an incomplete decomposition of cellulose and hemicelluloses contained in the material, which may have been caused by lignin (approx. 22\% content) blocking the availability of cellulose chains and hemicelluloses to enzymes.

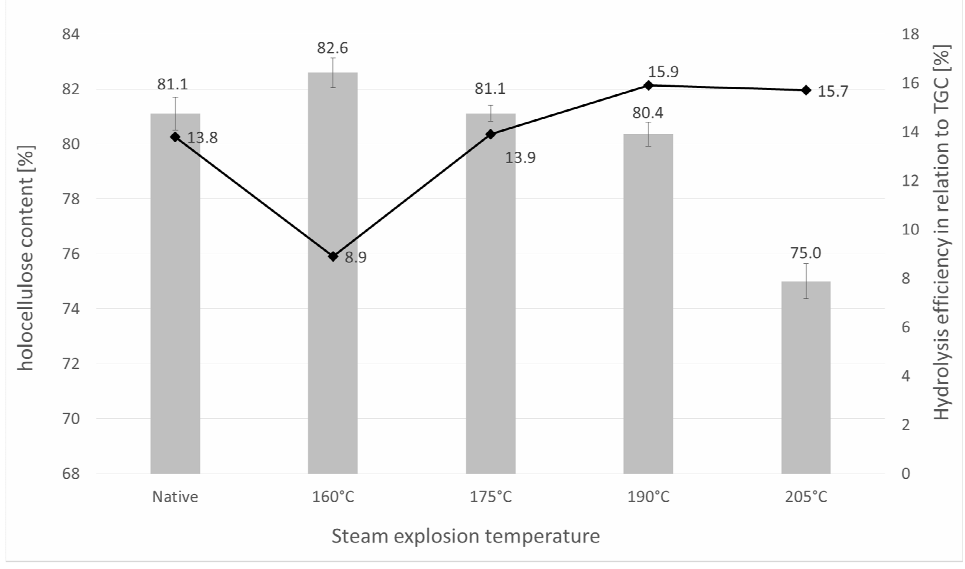

Figure 1: Glucose extraction efficiency of poplar biomass after steam treatment in relation to holocellulose content

Table 4

Monosaccharides and formic acid content in the liquid fraction for fast-growing poplar (MPK-4-11-2)

\begin{tabular}{lcccc}
\hline $\begin{array}{l}\text { Pretreatment } \\
\text { temperature }\end{array}$ & $\begin{array}{c}\text { Cellobiose } \\
(\mathrm{mg} / \mathrm{mL})\end{array}$ & $\begin{array}{c}\text { Glucose } \\
(\mathrm{mg} / \mathrm{mL})\end{array}$ & $\begin{array}{c}\text { Xylose } \\
(\mathrm{mg} / \mathrm{mL})\end{array}$ & $\begin{array}{c}\text { Formic acid } \\
(\mathrm{mg} / \mathrm{mL})\end{array}$ \\
\hline $160^{\circ} \mathrm{C}$ & 0.010 & 0.064 & 0.050 & 0.023 \\
$190^{\circ} \mathrm{C}$ & 0.005 & 0.061 & 0.098 & 0.070 \\
$205^{\circ} \mathrm{C}$ & $\mathrm{N} / \mathrm{D}$ & 0.010 & N/D & N/D \\
\hline
\end{tabular}

The highest glucose yield was obtained at 190 ${ }^{\circ} \mathrm{C}$ and $205{ }^{\circ} \mathrm{C}$, i.e. above $15 \%$. The corresponding samples had the holocellulose content of approx. $80 \%$ and $75 \%$, respectively. The sample pretreated at $205{ }^{\circ} \mathrm{C}$ has the lowest hemicellulose content (approx. 16\%) and almost the lowest lignin content - of $18 \%$. Meanwhile, the lignin content of the sample pretreated at 190 ${ }^{\circ} \mathrm{C}$ is comparable to that of the sample pretreated at $160{ }^{\circ} \mathrm{C}$ - of approx. $22 \%$.

The hydrolysis efficiency was determined by relating the content of obtained glucose to the theoretical maximum content of glucose that could be obtained from cellulose in the analyzed material. ${ }^{6,11}$ The hydrolysis yield in relation to the theoretical glucose content is comparable for the native material and the one pretreated at $175{ }^{\circ} \mathrm{C}$ and is about $14 \%$, while the holocellulose contents for these materials are similar.
Comparing the contents of structural components in the analyzed biomass (Table 2), it can be concluded that sample pretreated at $175{ }^{\circ} \mathrm{C}$ contains a lower amount of hemicelluloses than the native material - i.e. about $25 \%$, compared to almost $40 \%$ in the native material. Also, its cellulose content - of about 56\% - is higher than that of native biomass by about 15 percentage points. Native biomass has the insoluble lignin content lower by 3 percentage points compared to that of the sample pretreated at $175^{\circ} \mathrm{C}$.

Additionally, the liquid fraction was analyzed in terms of its content of glucose, cellobiose and xylose. The results of the analysis are presented in Table 4. The aim of this investigation was to determine the dissolution of sugars resulting from the breakdown of carbohydrates, such as cellulose and hemicelluloses, in transition from simple sugars to liquids. 
The presented results indicate thermal degradation of the carbohydrates that make up the lignocellulose biomass. The highest content of cellobiose was observed in the post-reaction fluid formed in the pretreatment process at $160{ }^{\circ} \mathrm{C}-$ i.e. $0.010 \mathrm{mg} / \mathrm{mL}$. The liquid fraction obtained after the treatment at $160{ }^{\circ} \mathrm{C}$ had the highest glucose content $(0.064 \mathrm{mg} / \mathrm{mL})$. The highest content of pentoses is noted for the material subjected to steam explosion at $190{ }^{\circ} \mathrm{C}$ (approx. $0.1 \mathrm{mg} / \mathrm{mL}$ ). The glucose content of this sample is comparable to that of the sample pretreated at 160 ${ }^{\circ} \mathrm{C}$, while its cellobiose content is lower - of about 0.005 . The lowest content of oligosaccharides and monosaccharides is characteristic of the reaction liquid after the pretreatment at $205{ }^{\circ} \mathrm{C}$. In this case, the glucose content of only $0.010 \mathrm{mg} / \mathrm{mL}$ was found.

A sample of liquid resulting from steam explosion at $175{ }^{\circ} \mathrm{C}$ was not analyzed because it presented mould growth. The sample was therefore rejected.

\section{Effect of steam explosion pretreatment on chemical composition of poplar samples}

The results obtained indicate a decrease in the content of extractives with the increase in the temperature of the steam explosion pretreatment, except in the case of the pretreatment at $205{ }^{\circ} \mathrm{C}$. This decrease may be caused by the disintegration of low-molecular organic compounds during the pretreatment, causing the formation of, e.g., formic acid. The final increase at $205{ }^{\circ} \mathrm{C}$ may be caused by low-molecular cellulose degradation. Due to the lack of sustained heating, there is a minimal breakdown of hemicelluloses to furfural and hydroxymethylfurfural, as presented in Table 4 and Figure 1.

Upon steam explosion, the content of cellulose in the material increased significantly in comparison with the native material. However, as the temperature increases, the cellulose content decreases slightly and remains more or less at a similar level. These changes in the cellulose content of the samples may be related to the degradation of sugars with a lower degree of polymerization (hemicelluloses), responsible for an apparent increase in cellulose content. ${ }^{50}$

A decrease in the hemicelluloses content was observed with the increase in the pretreatment temperature. An apparent overstatement of the cellulose content for the material pretreated at 160 ${ }^{\circ} \mathrm{C}$ may be associated with the degradation of part of the substance into the extraction fraction, apparently increasing the proportion of polysaccharides in the tested material. Hemicelluloses are the most easily thermally degradable substances. ${ }^{51}$ In this case, the greatest change in hemicelluloses was observed in comparison with other chemical components, which means that the steam explosion pretreatment leads to intensive degradation of hemicelluloses.

At $190{ }^{\circ} \mathrm{C}$, lignin is assumed to plasticize and the degradation of lower polymerization degree cellulose occurs (beta and gamma cellulose).$^{52} \mathrm{As}$ a result of the decomposition of hemicelluloses and cellulose with a lower degree of polymerization (Table 2), there is a decrease in the content of monosaccharides, which can be a substrate for enzymatic hydrolysis and an apparent increase in the content of high molecular substances, such as cellulose and lignin. ${ }^{20,53}$ As regards the pretreatment temperature of $205^{\circ} \mathrm{C}$, it is assumed that at this temperature a hard-soluble permanent lignocellulose complex is formed, which may affect the results obtained. ${ }^{39,50}$ This means that the change in the soluble lignin content is related to the thermal decomposition of low-molecular lignin and the formation of lignocellulose complexes.

The theoretical efficiency of hydrolysis cannot be directly related to the variable content of lignin and hemicelluloses. This issue is a much broader one. As a result of the analysis of SE pretreated wood biomass, a decrease in the extractives content at lower temperatures, of $160-190{ }^{\circ} \mathrm{C}$, is observed, which, once polysaccharides are formed from hemicelluloses, pass into the liquid and gaseous fractions resulting during sudden decompression of the system. They form a fraction suspected to inhibit the bioprocesses occurring during the extraction of liquid biofuels. ${ }^{54,55}$ This may be related to such biomass characteristics as the degree of crystallinity and polymerisation of cellulose. ${ }^{16}$ The chemical structure of lignin and the way it forms an LCC complex with polysaccharides found in this biomass can make a difference. ${ }^{56,57}$ Apart from the pretreatment at $160{ }^{\circ} \mathrm{C}$, it was observed that the pretreatment at the other temperatures used in the present investigation increased the yield of enzymatic hydrolysis. Moreover, comparing the findings of this study with the results reported by Szadkowski ${ }^{58}$ changes in the structure of porous wood biomass of California poplar can be observed, depending on SE process temperature and residence time. The results presented in 
Szadkowski's work ${ }^{58}$ indicate an increase in the amount of pores of $0.5-5 \mathrm{~nm}$ radius as a result of the increase in pretreatment temperature and residence time. Steam explosion pretreatment, without maintaining the heating, may increase the yield of monosaccharides in enzymatic hydrolysis, but this yield is still lower than that of processes with sustained process time at the same temperature.

\section{Sugar content in the liquid fraction}

From the tests carried out on the liquid resulting from the steam explosion pretreatment, it was observed that substances, such as monosaccharides (glucose, xylose), disaccharides (cellobiose) and formic acid, pass into the reaction liquid. It was not possible to determine the content of organic substances, such as furfural and hydroxymethylfurfural, in the tested liquid. It is known that these substances are produced by further thermal degradation of oligo- and monosaccharides. ${ }^{10,55}$

Comparing the content of cellulose degradation products in the post-reaction fluid, a decrease in their amount can be observed as the process temperature increases. ${ }^{58}$ Considering the literature data, it can be concluded that the increasing temperature leads to gradual decomposition of oligo- and monosaccharides into hydrolysis inhibitors, which are HMF and furfural. The presented results also indicate the breakdown of hemicelluloses and the transition of oligo- and monosaccharides that build them into the reaction fluid, leading to a decrease in the content of individual oligosaccharides in the biomass.

\section{Process cost estimation}

Table 5 shows the energy consumption as a function of the heating medium applied (steam and water), for individual temperatures of the steam explosion process, without sustained heating, assuming a single biomass charge of one ton. Due to the adopted green technology policy, we assume that, in the future, the pretreatment of lignocellulosic biomass for production of liquid fuels will be carried out with the use of electricity carriers and not by the conventional technology.

The highest energy consumption, depending on the carrier, occurs during the pretreatment at $205{ }^{\circ} \mathrm{C}$. When a carbon-heated water medium is used for the pretreatment, the difference between $205{ }^{\circ} \mathrm{C}$ and $160{ }^{\circ} \mathrm{C}$ is almost 1.5 times greater. For a treatment at comparable temperatures using steam, this difference is already 3.5 times greater.

According to data from 2019, with reference to the price of electricity quoted in USD, the most advantageous carrier is natural gas, with process costs for temperature levels of $160{ }^{\circ} \mathrm{C}$ and $205{ }^{\circ} \mathrm{C}$ of, respectively, $87582.64 \$$ and $115734.20 \$$ for water, and $134.16 \$$ and $471.66 \$$ for steam per $1 \mathrm{t}$ of wood biomass feedstock. The difference in processing wood biomass between $205{ }^{\circ} \mathrm{C}$ and $190{ }^{\circ} \mathrm{C}$ with steam is almost $70 \%$ lower than in the case of using water for the same temperatures. As shown in Figure 1, the yields of monosaccharides are comparable at these temperatures, so there is no need to increase the temperature to $205^{\circ} \mathrm{C}$, from an economic point of view, because this will generate additional costs. In the case of water treatment, these costs are similar. Heating to $190{ }^{\circ} \mathrm{C}$ is about $10 \%$ cheaper than heating to $205^{\circ} \mathrm{C}$. Considering the costs of the process, steam is a more suitable carrier.

Table 5

Costs of steam explosion pretreatment process depending on process temperature, type of medium and energy source

\begin{tabular}{|c|c|c|c|c|c|c|c|}
\hline \multirow{2}{*}{$\begin{array}{l}\text { Pretreatment } \\
\text { temperature }\end{array}$} & \multirow{2}{*}{$\begin{array}{l}\text { Type of } \\
\text { pretreatment } \\
\text { carrier }\end{array}$} & \multirow{2}{*}{$\begin{array}{c}\mathrm{Q} \\
(\mathrm{MJ})\end{array}$} & \multirow{2}{*}{$\begin{array}{l}\Delta \mathrm{T} \\
(\mathrm{K})\end{array}$} & \multicolumn{4}{|c|}{$\begin{array}{l}\text { Process cost as a function of power plant type } \\
\text { (USD) for } 1 \text { ton of biomass }\end{array}$} \\
\hline & & & & Nuclear & $\begin{array}{l}\text { Coal with } \\
\text { CCS }\end{array}$ & $\begin{array}{c}\text { CC Natural } \\
\text { gas }\end{array}$ & Biomass \\
\hline \multirow{2}{*}{$160^{\circ} \mathrm{C}$} & steam & 1124.0 & \multirow{2}{*}{140} & 290.16 & 405.60 & 134.16 & 287.04 \\
\hline & water & 7332500.0 & & 189422.92 & 264784.72 & 87582.64 & 187386.11 \\
\hline \multirow{2}{*}{$175^{\circ} \mathrm{C}$} & steam & 17622.5 & \multirow[b]{2}{*}{155} & 455.25 & 636.37 & 210.49 & 450.35 \\
\hline & water & 8118125.0 & & 209718.23 & 293154.51 & 96966.49 & 207463.19 \\
\hline \multirow{2}{*}{$190^{\circ} \mathrm{C}$} & steam & 26766.9 & \multirow{2}{*}{170} & 691.48 & 966.58 & 319.72 & 684.04 \\
\hline & water & 8903750.0 & & 230013.54 & 321524.31 & 106350.35 & 227540.28 \\
\hline \multirow{2}{*}{$205^{\circ} \mathrm{C}$} & steam & 39488.2 & \multirow{2}{*}{185} & 1020.11 & 1425.96 & 471.66 & 1009.14 \\
\hline & water & 9689375.0 & & 250308.85 & 349894.10 & 115734.20 & 247617.36 \\
\hline
\end{tabular}


The costs of the process at $175{ }^{\circ} \mathrm{C}$ and $190{ }^{\circ} \mathrm{C}$ are similar with regard to steam and water carriers, but each time heating the medium in the form of water is more expensive than steam. The costs of obtaining a SE temperature of $190{ }^{\circ} \mathrm{C}$ are $50 \%$ higher than those of $175{ }^{\circ} \mathrm{C}$, with comparable cellulose and hemicellulose contents. However, enzymatic hydrolysis of wood biomass treated at $190{ }^{\circ} \mathrm{C}$ allows obtaining higher content of monosaccharides, as shown in Figure 1.

Depending on the energy source, the cost of heating 1 ton of biomass during the SE pretreatment will be different. The biggest impact is produced by greenhouse gas emissions converted into $\mathrm{CO}_{2}$ emitted into the atmosphere. Regardless of the medium being heated, the highest cost was calculated for coal and the lowest - for gas. However, it is predicted that renewable energy sources (i.e. geothermal, wind, solar energy, etc.) will become cheaper as technologies develop and are introduced by the European Directive RED II. ${ }^{59}$ At an industrial scale, it is attractive to use water vapor as carrier for the pretreatment, as, in the worst case, it has more than 300 times lower process costs than the use of water.

On the basis of EU directive RED II ${ }^{59}$ it can be concluded that natural gas will be the most cost-effective source of electricity by 2030 , with increasing profitability of energy from biomass and other renewable sources.

\section{CONCLUSION}

The treatment of poplar wood biomass by steam explosion increases the yield of simple sugars in enzymatic hydrolysis. The pretreatment with steam explosion changes the chemical composition of poplar wood. The most favorable results considering the energy input were obtained for a steam explosion temperature of $190{ }^{\circ} \mathrm{C}$. The most cost-effective energy source for the steam explosion process using electric heating is natural gas. Further work is necessary to optimize the steam explosion process in order to improve the efficiency of the process.

\section{REFERENCES}

1 B. Yang, Z. Dai, S. Ding and C. E. Wyman, $\begin{array}{llll}\text { Biofuels, } & \text { 2, } & 421 & \text { (2011), }\end{array}$ https://doi.org/10.4155/bfs.11.116

2 S. V. Vassilev, D. Baxter, L. K. Andersen and C. G. Vassileva, Fuel, 89, 913 (2010), https//doi.org/10.1016/j.fuel.2009.10.022
3 Ustawa z dnia 25 sierpnia 2006 r. o biokomponentach i biopaliwach ciekłych, Dz.U. 2006, nr. 169 poz. 1199 [Act of the Parliament of the Republic of Poland of 25 August 2006 on biocomponents and liquid biofuels, Dz.U. 2006 No 169 pos. 1199]

4 G. Kłosowski, D. Macko and D. Mikulski, Och. Środ. $i$ Zas. Natur., 45, $118 \quad$ (2010), https://journals.indexcopernicus.com/search/article?arti cleId $=76238$

5 A. Stępień and I. Samson-Bręk, Ocena ryzyka inwestycyjnego i możliwości rozwoju działalności wytwórczej biopaliw zaawansowanych w Polsce ze szczególnym uwzględnieniem produkcji bioetanolu lignocelulozowego [Evaluation of investment risks and opportunities for the development of advanced biofuel production activities in Poland with particular emphasis on lignocellulosic bioethanol production], KIB, Warszawa, 2017

6 A. Antczak, K. Ziętek, M. Marchwicka, B. Tylko, A. Gawkowski et al., Przem. Chem., 95, 1770 (2016), https//doi.org/10.15199/62.2016.9.23

7 B. Igliński, R. Buczkowski and M. Cichosz, "Technologie bioenergetyczne - monografia", [Bioenergy Technologies - A Monograph], Wydawnictwo Naukowe Uniwersytetu Mikołaja Kopernika, Toruń, 2015, pp. 17-88, http://docplayer.pl/19789264-Technologiebioenergetyczne.html

8 W. M. Lewandowski, "Proekologiczne odnawialne źródła energii" [Environmentally Friendly Renewable Energy Sources], WNT, Warszawa, 2007, pp. 72-90

9 S. Haghighi Mood, A. H. Golfeshan, M. Tabatabaei, G. S. Jouzani, G. Najafi et al., Renew. Sustain. Energ. Rev., 27, 77 (2013), https://doi.org/10.1016/j.rser.2013.06.033

10 S. Prosiński, "Chemia Drewna" [Wood Chemistry], Państwowe Wydawnictwo Rolne i Leśne, 1984, pp. 50-54

11 M. M. Marchwicka, A. Radomski, A. Antczak, J. Szadkowski, A. Lewandowska et al., Przem. Chem., 94, 814 (2015), https://doi.org/10.15199/62.2015.5.34

12 Z. Fang, "Pretreatment Techniques for Biofuels and Biorefineries", Springer, Berlin, 2013, https://link.springer.com/content/pdf/10.1007/978-3 642-32735-3.pdf

13 A. K. Chandel, F. A. F. Antunes, R. Terán-Hilares, J. Cota, S. Ellila et al., in "Advances in Sugarcane Biorefinery: Technologies, Commercialization, Policy Issues and Paradigm Shift for Bioethanol and Byproducts", edited by A. K. Chandel, M. H. L. Silveira, Elsevier, Amsterdam, 2018, pp. 97-134, https://doi.org/10.1016/b978-0-12-804534-3.00005-7

14 J. Zawadzki, A. Radomski, A. Antczak and A. Kupczyk, in "Wyniki wybranych badań przeprowadzonych w ramach projektu WOODTECH", edited by S. Karpiński, Oficyna WydawniczoPoligraficzna ADAM, Warszawa, 2016, pp. 163-199 
15 J. Szadkowski, A. Radomski, A. Antczak, D. Szadkowska, A. Lewandowska et al., Przem. Chem., 96, 518 (2017), https://doi.org/10.15199/62.2017.3.4

16 E. Tomás-Pejó, P. Alvira, M. Ballesteros and M. J. Negro, Bioresour. Technol., 101, 4851 (2011), https://doi.org/10.1016/j.biortech.2009.11.093

17 D. Kim, Molecules, 23, 309 (2018), https://doi.org/10.3390/molecules23020309

18 K. Przybysz, H. Buzała, H. Kalinowska, E. Małachowska and P. Przybysz, Ind. Crop. Prod., 108, 824 (2017),

https://doi.org/10.1016/j.indcrop.2017.07.038

19 P. Alvira, E. Tomás-Pejó, M. Ballesteros and M. J. Negro, Bioresour. Technol., 101, 4851 (2010), https://doi.org/10.1016/j.biortech.2009.11.093

20 S. Sun, S. Sun, X. Cao and R. Sun, Bioresour. Technol., 199, $49 \quad$ (2016), https://doi.org/10.1016/j.biortech.2015.08.061

21 M. Wilk and M. Krzywonos, Przem. Chem., 94, 599 (2015), https://doi.org/10.15199/62.2015.4.20

22 I. Ballesteros, M. J. Negro, J. M. Oliva, A. Cabanas, P. Manzanares et al., Appl. Biochem. Biotechnol., $\quad$ 130, 496 (2006), https://doi.org/10.1385/ABAB:130:1:496

23 E. Chornet, C. Vanasse, J. P. Lemonnier and R. P. Overend, in "Research in Thermochemical Biomass Conversion", edited by A. V. Bridgwater, J. L. Kuester, Springer, Dordrecht, 1988, pp. 766-778, https://doi.org/10.1007/978-94-009-2737-7_58

24 B. Focher, A. Marzett and V. Crescenzi, in "Steam Explosion Techniques, Fundamentals and Industrial Applications", Gordon and Breach, Philadelphia, 1988, pp. 276-305

C. K. Kubicek, "Fungi and Lignocellulosic Biomass", John Wiley \& Sons Inc., 2013, pp. 129-215

26 Y. Sun and J. J. Cheng, Bioresour. Technol., 83, 1 (2002), https://doi.org/10.1016/S0960-8524(01)002127

27 A. Bauer, P. Bosch and A. Friedl, J. Biotechnol., 142 50

(2009),

https://doi.org/10.1016/j.jbiotec.2009.01.017

28 M. T. Holtzapple, A. E. Humphrey and J. D. Taylor, Biotechnol. Bioeng., 33, 207 (1989), https://doi.org/10.1002/bit.260330210

29 J. J. Young, H. S. Young, P. J. Hyung and Y. J. Kyung, J. Korean Wood Sci. Technol., 45, 182 (2017), https://doi.org/10.5658/WOOD.2017.45.2.182

30 F. Kačik and R. Solár, "Analytická Chémia Dreva", Tchnická Univerzta vo Zvolene, Zvolen, 1999, pp. 9162

31 V. Kučerová and E. Vybohova, Cellulose Chem. Technol., $\quad 52, \quad 381 \quad$ (2018), https://www.cellulosechemtechnol.ro/pdf/CCT56(2018)/p.\%20381-386.pdf

32 E. Palmqvist and B. Hahn-Hägerdal, Bioresour. Technol., $\quad \mathbf{7 4}, \quad 17$ (2000), https://doi.org/10.1016/S0960-8524(99)00160-1
33 E. Palmqvist and B. Hahn-Hägerdal, Bioresour. Technol., $\quad \mathbf{7 4}, \quad 25$ (2000), https://doi.org/10.1016/S0960-8524(99)00161-3

34 A. K. Chandel, S. S. Silva and O. V. Singh, in "Biofuel Production - Recent Developments and Prospects", edited by M. A. D. S. Bernardes, InTech, Rijeka, 2011, pp. 225-231, https://doi.org/10.5772/16454

35 L. J. Jönsson, B. Alriksson and N. O. Nilvebrant, Biotechnol. Biofuel., $\quad 6, \quad 1 \quad$ (2013), https://doi.org/10.1186/1754-6834-6-16

36 K. Przybysz, "Technologia celulozy i papieru" [Cellulose and Paper Technology], WSiP, Warszawa, 2007, pp. 79-137

37 A. Antczak, R. Świerkosz, M. Szeniawski, M. Marchwicka, F. Akus-Szylberg et al., Drewno, 63, 53 (2019), https://doi.org/10.12841/wood.16443985.D07.01

38 D. Szadkowska, Doctoral Thesis, Warsaw University of Life Sciences - SGGW, Warszawa, 2020

39 D. Fengel and G. Wegener, "Wood - Chemistry, Ultrastructure, Reactions", Walter de Gruyter, Berlin and New York, 2000, pp. 6-226, https://doi.org/10.1002/pol.1985.130231112

40 D. Klemm, B. Heublein, H. Fink and A. Bohn, Angew. Chem. Int. Ed., 44, 3358 (2005), https://doi.org/10.1002/anie.200460587

${ }_{41}$ K. Leja and M. Broda, Acta Sci. Pol., 8, 25 (2009), http://31.186.81.235:8080/api/files/view/4673.pdf

42 A. Antczak, M. Marchwicka, J. Szadkowski, M. Drożdżek, J. Gawron et al., Bioresources, 13, 8629 (2018), https://doi.org/10.15376/biores.13.4.8629-8645

43 B. Adney and J. Baker, Measurement of Cellulase Activities, LAP-006 NREL Analytical Procedure, National Renewable Energy Laboratory, Golden, 1996, https://www.nrel.gov/docs/gen/fy08/42628.pdf

44 A. Antczak, A. Radomski and J. Zawadzki, Annals of WULS For. Wood Tech., 58, 15 (2006)

45 K. Kürschner and A. Hoffer, Tech. Chem. Papier Zellstoff Fabr., 26, 125 (1929)

46 TAPPI T 222 om-02: Acid-insoluble lignin in wood and pulp, TAPPI test methods, Tappi Press, Atlanta,

2006 , https://www.tappi.org/content/SARG/T222.pdf

47 TAPPI UM 250: Acid-soluble lignin in wood and pulp, TAPPI test methods, Tappi Press, Atlanta, 1991, https://www.tappi.org/content/SARG/T250.pdf

${ }^{48}$ L. E. Wise, M. Murphy and A. A. D'Addieco, Pap. Trade J., 122, 2 (1946)

49 E. Dobrowolska and A. Kurowska, Wybrane zagadnienia $\mathrm{Z}$ hydrotermicznej obróbki drewna w zadaniach, Wydawnictwo: SGGW, Warszawa, 2016, pp. 7-103

F. Akus-Szylberg, A. Antczak, O. Bytner, K. Krajewski and J. Zawadzki, Annals of WULS, For. Wood Tech., 104, $386 \quad$ (2018), https:/wulsannals.com/resources/html/article/details?i $\mathrm{d}=214086$ 
51 J. M. Boonstra, J. Van Acker, B. F. Tjeerdsma and E. V. Kegel, Annals Forest Sci., 64, 679 (2007), https://doi.org/10.1051/forest:2007048

52 Y. Yu and H. Wu, Ind. Eng. Chem. Res., 49, 3902 (2010), https://doi.org/10.1021/ie901925g

53 K. Przybysz-Buzała, P. Przybysz, K. Kalinowska, K. Przybysz, M. Kucner et al., Cellulose, 23, 649 (2015), https://doi.org/10.1007/s10570-015-0808-7

54 R. Balan, A. Antczak, S Brethauer, T. Zielenkiewicz and M. H. Studer, Energies, 13, 3653 (2020), https://doi.org//10.3390/en13143653

55 R. Balan, A. Antczak, S Brethauer, T. Zielenkiewicz and M. H. Studer, Energies, 13, 3638 (2020), https://doi.org/10.3390/en13143638

56 D. Xueyu, G. Goran and J. Li, Planet J., 74, 421 (2013), https://doi.org/10.4155/BFS.11.116

57 Y. Liu, Q. Wang, Q. Xia and J. Li, ChemSusChem, 10, 1692

(2017),
58 J. Szadkowski, Doctoral Thesis, Warsaw University of Life Sciences - SGGW, Warszawa, 2019

59 REGULATIONS (EU) 2018/1999 OF EUROPEAN PARLIAMENT AND OF THE COUNCIL of 11 December 2018 on the Governance of the Energy Union and Climate Action, amending Regulations (EC) No 663/2009 and (EC) No 715/2009 of the European Parliament and of the Council, Directives 94/22/EC, 98/70/EC, 2009/31/EC, 2009/73/EC, 2010/31/EU, 2012/27/EU and 2013/30/EU of the European Parliament and of the Council, Council Directives 2009/119/EC and (EU) 2015/652 and repealing Regulation (EU) No 525/2013 of the European Parliament and of the Council, https://eur-lex.europa.eu/legalcontent/en/TXT/PDF/?uri=CELEX:32018R1999\&fro $\mathrm{m}=\mathrm{EN}$

https://doi.org/10.1002/cssc.201601795 